\title{
Contributions of anoxygenic and oxygenic phototrophy and chemolithotrophy to carbon and oxygen fluxes in aquatic environments
}

\author{
John A. Raven* \\ Division of Plant Sciences, University of Dundee at Scottish Crop Research Institute, Invergowrie, Dundee DD2 5DA, UK
}

\begin{abstract}
Estimates of aquatic primary productivity at local, regional or global scales commonly concentrate on oxygenic photolithotrophy. The analysis presented here briefly considers the occurrence and metabolism of other autotrophs sensu lato, i.e. not just the organisms with an autotrophic inorganic carbon assimilation machinery. These other autotrophs include chemolithotrophs and anoxygenic photolithotrophs, of which some use the photosynthetic carbon reduction cycle as do oxygenic photolithotrophs, while others use one of 4 other pathways. The category of other autotrophs also includes organisms that possess photochemical energy transduction machinery but lack autotrophic carbon assimilation; light stimulates the growth rates of these autotrophs and/or increases the fraction of the organic carbon substrate used that is converted into cell material when using light energy. Organisms lacking autotrophic inorganic carbon assimilation influence food webs by increasing the rate, or efficiency, of conversion of dissolved organic carbon ultimately derived from autotrophic inorganic carbon assimilation into particulate organic carbon. Chemolithotrophs and anoxygenic autotrophs today depend on the activities of oxygenic chemolithotrophs for one or more of their growth substrates, and thus contribute to global net primary productivity but not to global gross primary productivity. Global net aquatic primary productivity by oxygenic photo-

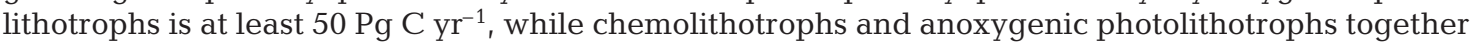
contribute about 0.40 $\mathrm{Pg} \mathrm{C} \mathrm{yr}^{-1}$. Before the occurrence of oxygenic photolithotrophs in the Archaean, chemolithotrophs and anoxygenic photolithotrophs had a net primary productivity of about 3.4 Pg C $\mathrm{yr}^{-1}$, which is higher than the present values largely because anoxygenic photolithotrophs were able to inhabit the euphotic zone worldwide.
\end{abstract}

KEY WORDS: Archaean · 3-hydroxypropionate pathway · Inorganic carbon concentrating mechanisms - Photosynthetic carbon reduction cycle $\cdot$ Reductive tricarboxylic acid cycle $\cdot$ Resource use Ribulose bisphosphate carboxylase-oxygenase

\section{INTRODUCTION}

Marine net primary productivity, estimated from measurements of the conversion of inorganic to organic carbon that are as direct as possible, has been estimated at about $50 \mathrm{Pg} \mathrm{C} \mathrm{yr}{ }^{-1}$, with almost all of this conversion carried out by oxygenic phytoplankton organisms (Field et al. 1998). The corresponding value for terrestrial systems is about $55 \mathrm{Pg} \mathrm{C} \mathrm{yr}^{-1}$ (Field et al. 1998), with a contribution from inland waters that is globally very small but locally highly significant (Raven \& Maberly 2005). Estimates of gross aquatic (almost all marine) primary productivity based on respiration rates, assuming that organic carbon inputs into rivers each year are equal to marine sedimentation of organic carbon, are about 170 to $200 \mathrm{Pg} \mathrm{C} \mathrm{yr}^{-1}$ (del Giorgio \& Williams 2005). For the open ocean, where the most direct comparisons are possible, and allowing for possible underestimates of net primary production and the need to convert this to gross primary produc- 
Table 2. Summary of the aquatic phototrophic and chemolithotrophic micro-organisms and some of their metabolic characteristics. See text for details and references

\begin{tabular}{|c|c|c|c|c|c|}
\hline Metabolism & $\begin{array}{l}\text { Representative } \\
\text { organisms }\end{array}$ & $\begin{array}{l}\text { Electron } \\
\text { donor }\end{array}$ & $\begin{array}{l}\text { Electron } \\
\text { acceptor }\end{array}$ & $\begin{array}{l}\text { Photo- } \\
\text { chemistry }\end{array}$ & $\begin{array}{l}\text { Autotrophic } \mathrm{CO}_{2} \\
\text { fixation pathway }\end{array}$ \\
\hline \multicolumn{6}{|l|}{ Chemolithotrophs } \\
\hline Anammox & Bacteria & $\mathrm{NH}_{4}^{+}$ & $\mathrm{NO}_{2}^{-}, \mathrm{CO}_{2}$ & None & Acetyl CoA pathway \\
\hline $\begin{array}{l}\mathrm{Fe}^{2+} \text { oxidizers, nitrifiers, } \\
\mathrm{S}^{2-} \text { oxidisers }\end{array}$ & Archaea, Bacteria & $\begin{array}{l}\mathrm{Fe}^{2+}, \mathrm{NH}_{4}^{+}, \\
\mathrm{NO}_{2}{ }^{-}, \mathrm{S}^{2-}\end{array}$ & $\mathrm{O}_{2}, \mathrm{CO}_{2}$ & $\begin{array}{l}\text { None } \\
\text { obligatory }\end{array}$ & $\begin{array}{l}\text { Rubisco/PCRC, } \\
\text { 3-HO-propionate, } \\
\text { 3-HO-propionate/ } \\
\text { 4-HO-butyrate, dicarboxylate/ } \\
\text { 4-HO-butyrate }\end{array}$ \\
\hline \multicolumn{6}{|c|}{ Non-photolithotrophic anoxygenic phototrophs } \\
\hline $\begin{array}{l}\text { Bacterio-rhodopsin-like } \\
\text { pigments }\end{array}$ & $\begin{array}{l}\text { Archaea, } \\
\text { Proteobacteria }\end{array}$ & Organic & Organic & $\begin{array}{l}\text { Actino-, bacterio-, } \\
\text { halo-, proteo- } \\
\text { rhodopsin }\end{array}$ & None \\
\hline $\begin{array}{l}\text { Anoxic, anoxygenic, } \\
\text { bacterio-chlorophyll }\end{array}$ & Heliobacteria & Organic & Organic & $\begin{array}{l}\text { Bacterio- } \\
\text { chlororophyll, } \\
\text { PSI-like }\end{array}$ & None \\
\hline $\begin{array}{l}\text { Aerobic, anoxygenic } \\
\text { bacterio-chlorophyll }\end{array}$ & $\begin{array}{l}\text { Proteobacteria } \\
\text { The acidobacterium } \\
\text { 'Candidatus } \\
\text { Chloracidobacterium } \\
\text { thermophilum' }\end{array}$ & Organic & Organic & $\begin{array}{l}\text { Bacterio- } \\
\text { chlorophyll, } \\
\text { PSII-like }\end{array}$ & None \\
\hline $\begin{array}{l}\text { Aerobic anoxygenic } \\
\text { chlorophyll }\end{array}$ & $\begin{array}{l}\text { The cyanobacterium } \\
\text { UCYN-A }\end{array}$ & Organic & Organic & $\begin{array}{l}\text { Chlorophyll, } \\
\text { PSI }\end{array}$ & None \\
\hline $\begin{array}{l}\text { Photolithotrophic anoxys } \\
\text { Direct photo-chemical } \\
\text { reduction of NAD }{ }^{+}\end{array}$ & $\begin{array}{l}\text { genic phototrophs } \\
\text { Chlorobi } \\
\text { (obligate anaerobes) }\end{array}$ & $\mathrm{S}^{2-}, \mathrm{Fe}^{2+}$ & $\mathrm{CO}_{2}$ & $\begin{array}{l}\text { Bacterio-chlorophyll, } \\
\text { PSI-like }\end{array}$ & RTCAC \\
\hline \multirow{2}{*}{$\begin{array}{l}\text { Indirect photo-reduction } \\
\text { of } \mathrm{NAD}^{+} \text {, only photo- } \\
\text { trophic under anoxia }\end{array}$} & \multirow{2}{*}{$\begin{array}{l}\text { Chloroflexi and Proteo- } \\
\text { bacteria (purple sulfur } \\
\text { and non-sulfur bacteria) }\end{array}$} & & & $\begin{array}{l}\text { Bacteriochlorophyll, } \\
\text { PSII-like }\end{array}$ & 3-HO-propionate \\
\hline & & Organic, $\mathrm{S}^{2-}$ & $\mathrm{CO}_{2}$ & $\begin{array}{l}\text { Bacteriochlorophyll, } \\
\text { PSII-like }\end{array}$ & Rubisco IA,IC,II/PCRC \\
\hline \multirow[t]{2}{*}{$\begin{array}{l}\text { Oxygenic photo- } \\
\text { lithotrophs }\end{array}$} & $\begin{array}{l}\text { Cyanobacteria (except } \\
\text { UCYN-A) }\end{array}$ & $\mathrm{H}_{2} \mathrm{O}$ & $\mathrm{CO}_{2}$ & $\begin{array}{l}\text { Chlorophyll, } \\
\text { PSI + PSII }\end{array}$ & Rubisco IA,IB/PCRC \\
\hline & $\begin{array}{l}\text { Algae (except) mixotrophic } \\
\text { and obligately chemo- } \\
\text { organotrophic species }\end{array}$ & $\mathrm{H}_{2} \mathrm{O}$ & $\mathrm{CO}_{2}$ & $\begin{array}{l}\text { Chlorophyll, } \\
\text { PSI + PSII }\end{array}$ & Rubisco IB,ID,II/PCRC \\
\hline
\end{tabular}

autotrophs sensu lato. In view of the importance of oxygenic photolithotrophs in most extant aquatic environments, this paper starts with a brief summary of these organisms and their roles in the ecology of other autotrophs, even though representatives of the other categories of autotrophs preceded oxygenic photolithotrophs in the sequence of metabolic types on Earth.

\section{METABOLIC STRATEGIES OF AQUATIC MICROBES}

\section{Oxygenic photolithotrophs}

The group of oxygenic photolithotrophs includes the cyanobacteria and photolithotrophic eukaryotes. Their photochemistry involves chlorophyll-based Photosystems I and II (PSI and PSII) acting in series (Falkowski \& Raven 2007; Table 2). PSI and PSII and the bacteriochlorophyll-based photosystems in anoxygenic photo- synthetic bacteria are all derived from a common ancestral photosystem (Raymond et al. 2003, Sadekar et al. 2006).

While oxygenic photolithotrophs typically occur in oxygenated environments, anoxygenic autotrophic photosynthetic bacteria can only grow photolithotrophically under anoxic or very hypoxic conditions (considered below). Conversely, oxygenic photolithotrophs typically grow in inorganic carbon concentrations that are much closer to air equilibrium with respect to $\mathrm{CO}_{2}$ than is the case for the anoxygenic autotrophic photosynthetic bacteria. This is because the anoxic habitats are generated by sedimentation of organic matter in an environment in which oxygen is consumed in respiration faster than it can be supplied from more oxygenated waters. This relative isolation causes a buildup of the $\mathrm{CO}_{2}$ generated by the predominant chemo-organotrophic metabolism. Oxygenic photolithotrophs invariably use the photosynthetic carbon reduction cycle (PCRC) (Table 1), a pathway that 
was discovered in green microalgae, and even those Rubiscos which have the highest affinity for $\mathrm{CO}_{2}$, highest $\mathrm{CO}_{2} / \mathrm{O}_{2}$ selectivity and consequent lowest $\mathrm{CO}_{2}$-saturated specific reaction rate (Tcherkez et al. 2006), are scarcely $\mathrm{CO}_{2}$-saturated in the air-equilibrium $\mathrm{CO}_{2}$ concentrations at the temperatures at which they live. In the water, then, slower diffusion of $\mathrm{CO}_{2}$ and $\mathrm{O}_{2}$ through water than through air implies lower $\mathrm{CO}_{2} / \mathrm{O}_{2}$ ratios at the Rubisco active site and, hence, lower carboxylation rates and higher oxygenation rates than in air for the same enzyme and cellular structure.

In all cyanobacteria and most aquatic photosynthetic eukaryotes, inorganic carbon concentrating mechanisms (CCMs) increase the $\mathrm{CO}_{2}$ concentration around Rubisco during steady-state photosynthesis to concentrations higher than those in the bulk medium (Giordano et al. 2005, Raven et al. 2008a,b). Analysis of the gene sequence of Rubiscos shows that there are 4 main groups, denoted Forms I, II, III and IV. Of these, the main forms involved in carboxylation in nature are Form I, with 8 large (catalytic) and 8 small subunits, and Form II, with 2 large subunits (Badger \& Bek 2008, Tabita et al. 2008). Form I Rubiscos are in turn subdivided into Forms IA, IB, IC and ID that, with Form II, have characteristic phylogenetic distributions and ranges of kinetic properties (Badger \& Bek 2008). Most cyanobacteria, like glaucocystophyte and chlorachniophyte, chlorophyte and euglenophyte algae, as well as embryophytic plants, have Form IB Rubiscos. However, Form IA Rubisco, and fewer CCM components, exist in the open-ocean Prochlorococcus and Synechococcus strains ( $\alpha$-cyanobacteria) than in coastal and freshwater $\beta$-cyanobacteria with Form IB Rubiscos. The $\beta$-cyanobacteria represent the ancestral condition of inorganic carbon assimilation (Price et al. 2008). Form ID Rubiscos occur in red algae and the algae that gained photosynthesis from red algae by secondary endosymbiosis; most eukaryotic marine phytoplankton today have Form ID Rubiscos. The exception are dinoflagellates, which almost all have a Form II Rubisco. Nevertheless, even the phytoplankton with Rubiscos that have kinetic properties most conducive to effective inorganic carbon assimilation using diffusive $\mathrm{CO}_{2}$ entry have CCMs (Giordano et al. 2005, Raven et al. 2008a,b).

CCMs in cyanobacteria are all based on active transport of $\mathrm{HCO}_{3}^{-}$or entry of $\mathrm{CO}_{2}$ followed by energized conversion to $\mathrm{HCO}_{3}{ }^{-}$in the cytosol, followed by carbonic anhydrase-catalysed conversion of $\mathrm{HCO}_{3}{ }^{-}$to $\mathrm{CO}_{2}$ in carboxysomes, which house all of the Rubisco (Price et al. 2008). The occurrence of Rubisco and the PCRC is a necessary, but not sufficient, condition for the occurrence of carboxysomes in other autotrophic bacteria. Carboxysomes occur in several chemolitho- trophs, but very rarely in anoxygenic phototrophs, which use the PCRC (Codd \& Marsden 1984, Cannon et al. 2001). The relation between the occurrence of carboxysomes, the kinetics of Rubisco, and the inorganic carbon availability in the environment of autotrophic Bacteria other than cyanobacteria, has not yet been adequately explored (Badger \& Bek 2008).

Less is known about the CCMs of eukaryotic algae, but in most organisms they are thought to involve active entry of one or more inorganic carbon species, often with pyrenoids in the plastids as the analogues of carboxysomes. $\mathrm{C}_{4}$-like inorganic carbon assimilation, presumably with a contribution of this pathway to the CCM, has been suggested in the diatom Thalassiosira weissflogii on the basis of enzyme localization and short-term labelling with inorganic ${ }^{14} \mathrm{C}$ (Reinfelder et al. 2000). Subsequent labelling studies showed that the pattern in this algae was more like that of a $\mathrm{C}_{3}-\mathrm{C}_{4}$ intermediate flowering plant, with $\mathrm{C}_{3}$ biochemistry following the action of a CCM in T. pseudonana (Roberts et al. 2007a,b). The complete genome sequence of $T$. pseudonana (Armbrust et al. 2004) shows the presence of the genes encoding the enzymes needed for $\mathrm{C}_{4}$ metabolism. However, these genes are widespread among oxygenic eukaryotes and have a number of metabolic roles, and cannot be taken to indicate $\mathrm{C}_{4}$ metabolism. Transcriptome studies are in general agreement with the labelling studies on $T$. pseudonana in not supporting the occurrence of $\mathrm{C}_{4}$ metabolism (Roberts et al. 2007a,b, McGinn \& Morel 2008); however, inhibitor studies have been used to support the presence of $\mathrm{C}_{4}$ photosynthesis in the 2 Thalassiosira species and the diatom Phaeodactylum tricornutum. Kroth et al. (2008, see also Bowler et al. 2008) show from genomic studies that $\mathrm{C}_{4}$ photosynthesis is unlikely to occur in the diatom $P$. tricornutum despite the occurrence of the appropriate genes in the completely sequenced genome, which is in agreement with Cassar $\&$ Laws (2007). These results show that genomic data must be used with caution in drawing conclusions about metabolic pathways when the genes involved are components of more than one pathway.

The CCMs are one sort of carbon pump; ecologically, there is an ecosystem-scale biological carbon pump resulting from sedimentation of particulate organic carbon from oxygenic primary production down the water column. In the context of the present paper, this is important as a factor in providing habitats for other kinds of autotrophs. When the oxygen requirement for the aerobic microbial oxidation of the non-refractory component of the organic carbon is greater than the rate at which oxygen is supplied advectively in solution, microbial metabolism gives hypoxic, then anoxic conditions, with the sequential use of nitrate (by means of ammonification, denitrification, anaerobic ammo- 
nium oxidation or anammox), sulfate (by means of dissimilatory sulfate reduction) and carbon dioxide (by means of methanogenesis) as electron acceptors. As will be seen below in 'Chemolithotrophs', the anammox reaction supports chemolithotrophy, and methanogenesis from carbon dioxide is a reductive process akin to autotrophy, while the sulfide resulting from sulfate reduction provides the substrate for photolithotrophic sulfide oxidation in illuminated anoxic habitats and for sulfide-based chemolithotrophy at the oxycline. Chemolithotrophic sulfide oxidation involves oxygen, nitrate or nitrite as an electron acceptor, while the anammox reaction uses nitrite in oxidising ammonium. Biologically (i.e. in addition to lightning, Raven \& Yin 1998), nitrate and nitrite result from nitrification in the water body; this depends on oxygen and also involves chemolithotrophic inorganic carbon assimilation. Dissolved organic carbon, ultimately from oxygenic photolithotrophy, supports the autotroph-like light-stimulated growth of aerobic anoxygenic photosynthetic Bacteria, as well as Bacteria and Archaea with rhodopsin-like energy-converting pigments. These too are discussed in the next section.

Another important influence of oxygenic photolithotrophs on anoxygenic photolithotrophs is shading. Stomp et al. (2007b) have reinvigorated the longstanding debate on 'complementary chromatic adaptation' of oxygenic photolithotrophs in relation to the predominant wavelengths in their natural underwater environment as a function of lake or ocean chemistry, and depth. Raven \& Wolstencroft (2004), Kiang et al. $(2007 \mathrm{a}, \mathrm{b})$ and Stomp et al. (2007a) also revisit the extent to which absorption of electromagnetic radiation by water and by oxygenic photolithotrophs affects the wavelengths available to anoxygenic photolithotrophs. This is dealt with in more detail in the next 2 sections when the various anoxygenic photosynthetic bacteria are considered.

Some properties of oxygenic photolithotrophs are outlined in Table 2.

\section{Organisms with energy-transforming photochemistry but not capable of autotrophic $\mathrm{CO}_{2}$ assimilation}

Organisms considered under this heading are Archaea and Bacteria with rhodopsin-like pigmentprotein complexes whose photochemistry results in the generation of an ion electrochemical potential difference across the plasma membrane but not in oxidised and reduced products (see Table 2). Also considered are those anoxygenic bacteria that grow chemo-organotrophically or photo-organotrophically and with, at most, a facultative and limited capacity for autotrophic inorganic carbon assimilation (see Table 2).
The occurrence of the rhodopsin-like photochemical energy conversion systems (bacteriorhodopsin and halorhodopsin) in Archaea from hypersaline environments has been known for over 3 decades (Oesterhelt \& Stoeckenius 1973). Even before the advent of genomic techniques, the ecology, photochemistry and physiology of these organisms was well understood. The 2 rhodopsin-like pigments were expressed mainly under anoxic conditions, where the input of photochemical energy enabled the production of more biomass per unit organic substrate consumed than if fermentation was the only energy source for growth. The contribution of photochemical energy to organotrophic growth under aerobic conditions was minimal, and there was little evidence for autotrophic inorganic carbon assimilation under any condition (Danon \& Caplan 1977, Danon 1983, Moran \& Miller 2007).

Genomic studies were instrumental in showing that these rhodopsin-like photochemical energy transducers occurred in Bacteria (as proteorhodopsin in marine forms and as actinorhodopsins in freshwater and estuarine forms) and (as proteorhodopsins) in a range of Archaea ( $\mathrm{Ng}$ et al. 2000, Béjà et al. 2001, Baliga et al. 2004, Giovannoni et al. 2005, Mongodin et al. 2005, Atamna-Ismaeel et al. 2008, Sharma et al. 2008). There is evidence of genotypic difference in the absorption spectra of proteorhodopins from marine environmental samples that may be related to the predominant wavelengths incident on the organisms in their natural environment (Man et al. 2003). Only sensory rhodopsins occur in oxygenic photolithotrophs (e.g. Merchant et al. 2007).

The global significance of the energy-transducing rhodopsins in energy flow and element cycling in aquatic ecosystems is unclear. References in the previous paragraph show the general absence from their genomes of mechanisms of autotrophic inorganic carbon assimilation. Such stimulation by light of chemoorganotrophic growth in principle can be attributed to the lower respiratory loss of organic substrate in growth and maintenance when there is the possibility of supplementing the respiratory or fermentative energy supply with photochemical energy.

A number of bacteriochlophyll-containing Bacteria can grow chemo-organotrophically or photo-organotrophically, with no supplementation by autotrophic inorganic carbon fixation. Heliobacteriaceae with PSItype reaction centres are strict anaerobes that can grow photo-organotrophically in the light and fermentatively in the dark (Gest \& Blankenship 2004, Heinnickel \& Golbeck 2007, Sattley et al. 2008). Their inability to bring about autotrophic inorganic carbon assimilation is attributable to the absence of ATP-citrate lyase; the other reactions of the reductive tricar- 
boxylic acid cycle (RTCAC) occur in these organisms (Pickett et al. 1994, Sattley et al. 2008). These organisms are found mainly in soil, and their occurrence in aquatic environments is apparently restricted to rice paddy soils and certain hot springs.

This restricted range of aquatic habitats occupied by Heliobacteriacae contrasts with the habitat area available to the other category of non-autotrophic bacteriochlorophyll-containing organisms, i.e. the aerobic anoxygenic photosynthetic bacteria: they are found throughout the surface ocean and also occur in fresh water (Yurkov \& Beatty 1998, Gest \& Blankenship 2004, Moran \& Miller 2007, Sattley et al. 2008). These organisms express their photosynthetic apparatus, with a Photosystem II (PSII)-like reaction centre, under aerobic conditions and carry out photochemistry and photo-organotrophy if there is sufficient high irradiation at the appropriate wavelengths. The light-harvesting pigments of these organisms are similar to those of the proteobacterial non-sulfur photosynthetic bacteria, even though they can live much closer to the surface than is true for most of their relatives that cannot carry out photosynthetic reactions under aerobic conditions. This means that the selective pressures on the wavelengths at which the photosynthetic apparatus absorbs (Kiang et al. 2007a,b, Stomp et al. 2007a,b) may be somewhat relaxed. The fully sequenced genomes of these organisms lack genes that would allow any of the known pathways of autotrophic inorganic carbon assimilation, which is in agreement with the absence of growth when inorganic carbon is the only carbon source (Fuchs et al. 2007, Moran \& Miller 2007, Swingley et al. 2007).While these organisms do not seem, on the basis of genome studies, to be diazotrophs, some legumes have stem nodules with diazotrophic symbiotic rhizobia carrying out aerobic anoxygenic photosynthesis (Giraud \& Fleischman 2004).

These organisms can grow chemo-organotrophically or photo-organotrophically. Bacteriochlorophyll synthesis occurs in the dark, and relatively low irradiances suffice to substantially inhibit this synthesis (reviewed by Biebl \& Wagner-Döbler 2006). However, natural diel light-dark alternations are sufficient to maintain photochemically significant levels of photosynthetic apparatus in at least some strains (Yurkov \& van Gemerden 1993, Kolber et al. 2001, Biebl \& WagnerDöbler 2006), and pigment synthesis can also be stimulated by low levels of organic substrates (Biebl \& Wagner-Döbler 2006).

Also belonging in this ecological group, but not yet examined for the possibility of photolithotrophic growth, is a member of the Acidobacteria, 'Candidatus Chloracidobacterium thermophilum' (Bryant et al. 2007). This organism, from phototrophic microbial mats in a hot spring, was characterised using an exem- plary synergistic combination of metagenomic and classical microbiological enrichment culture techniques. These methods showed the occurrence of a PSII-like reaction centre and light stimulation of chemo-organotrophic growth (Bryant et al. 2007).

Further aerobic anoxygenic phototrophs are the globally distributed diazotrophic cyanobacteria, termed UCYN-A (Zehr et al. 2008). These uncultured organisms have been characterised using genomic techniques from environmental samples highly enriched in the diazotroph by cell sorting based on fluorescence, using quantitative fluorescence real-time PCR of a nitrogenase gene. The cells lacked the genes for PSII and for autrotrophic inorganic carbon assimilation, and presumably bring about photo-organotrophic and/or chemo-organotrophic aerobic $\mathrm{N}_{2}$ fixation (cf. Giraud \& Fleischman 2004).

Light stimulation of chemo-organotrophic growth is, as in the organisms with energy-transducing rhodopsins, presumably a result of increased conversion of the dissolved organic matter consumed into cell material rather than $\mathrm{CO}_{2}$. This is a result of the supplementation, and partial replacement, of light-independent bioenergetic processes with those driven by photochemistry (Kolber et al. 2001, Goericke 2002, Moran \& Miller 2007). There is still uncertainty as to the effect of bacteriochlorophyll-based photo-organotrophy on the overall bacterial organotrophy in the surface ocean: a value on the order of a $1 \%$ enhancement of overall organotrophic bacterial growth (i.e. including bacteria that lack energy-transforming photochemistry) seems appropriate on the basis of present knowledge (Goericke 2002, Moran \& Miller 2007). The increase for the bacteriochlorophyll-containing bacteria is, of course, larger, and could well be evolutionarily significant for them. How important this enhancement is for food web function awaits further research. Even in the hypothetical case of bacterial organotrophic growth in the surface ocean (units of bacterial C per unit area and time) consuming all the net primary productivity (in the same units) in the surface ocean (Hoppe et al. 2002), the overall light stimulation of bacterial chemoorganotrophic productivity is only $1 \%$ of net primary productivity. This is smaller than their contribution to overall primary photochemistry in the ocean as estimated from fast repetition rate (i.e. bacterio-) chlorophyll fluorescence measurement (Kolber et al. 2001). Even a rough estimate does not yet seem possible for the global contribution of organisms containing energy-transforming rhodopsins to biogeochemical cycles and energy flow (Moran \& Miller 2007).

These organisms cannot be legitimately regarded as primary producers since, although they use light energy, all of their carbon other than the inorganic carbon used in anaplerotic pathways ultimately comes 
from (almost always oxygenic) photolithotrophs. The question of whether these organisms could confound measurements of primary productivity in environmental samples is discussed later with a similar discussion of the possible influences of anoxygenic photolithotrophs and chemolithotrophs.

\section{Anoxygenic photosynthetic organisms with autotrophic inorganic carbon assimilation}

All anoxygenic photosynthetic Bacteria with the potential for autotrophic inorganic carbon assimilation can only photosynthesise under anoxic conditions (Table 2). Of these, the green sulfur bacteria (Chlorobi) are obligate anaerobes and obligate photolithotrophs, and they have PSI-like reaction centres (Frigaard et al. 2003, Bryant \& Frigaard 2006) (Table 2). The Chlorobi use sulfide and ferrous iron as their source of reductant (Crowe et al. 2008). Chloroflexi, and potentially phototrophic members of the Proteobacteria, are all capable of aerobic, or at least microaerophilic, organotrophy in the dark. Anoxic conditions are required for photolithotrophic or photo-organotrophic growth in the light by Chloroflexi and Proteobacteria, using PSII-like reaction centres (Bryant \& Frigaard 2006) (Table 2).

The Chlorobi are the organisms in which the RTCAC (Tables $1 \& 2$ ) autotrophic pathway of inorganic carbon assimilation was characterised using tracer labelling and enzymology (Sirevåg 1995). The complete gene sequence of Chlorobium tepidum showed that there were no pathways of autotrophic inorganic carbon assimilation other than the RTCAC in this organism, although there was a gene for a Form IV Rubisco that does not function as a carboxylase (Eisen et al. 2002). The low inorganic carbon affinity of the RTCAC (Table 1) is presumably not a problem in the anoxic and, hence, relatively high $\mathrm{CO}_{2}$ environments of the Chlorobi. More work is needed on the inorganic carbon availability to chemolithotrophs with this pathway (see 'Chemolithotrophs' for further details on the occurrence of the RTCAC).

Pre-genomic work using tracer labelling and enzymology showed that the purple sulfur (and purple nonsulfur) Proteobacteria used the PCRC for autotrophic inorganic carbon assimilation (Tabita 1995) (Table 2). Complete genome sequences of purple photosynthetic bacteria showed no autotrophic pathways other than the PCRC (e.g. Larimer et al. 2004, Tabita et al. 2008) (Tables 1 \& 2). Metagenomics showed the distribution of Forms IA, IC and II among the purple bacteria, often with more than one form in a single organism (Tabita et al. 2008). There are plausible ecological rationalisations for these distributions; however, while these rela- tionships to the ecology of the organisms rely on kinetic studies of Rubisco from individual organisms, these studies do not give sufficiently precise kinetic data to relate the Rubisco form to ecological interactions (Badger \& Bek 2008).

The 3-hydroxypropionate pathway in Chloroflexus has been almost completely elucidated. It is now known to function as a bi-cycle involving 2 carboxylations by acetyl-CoA-carboxylase for every 1 by propionyl-CoA-carboxylase, and the product is a 3carbon compound (Herter et al. 2002, Friedmann et al. 2006, Klatt et al. 2007), so the previously suggested involvement of the photorespiratory carbon oxidation cycle (PCOC) (see Sirevåg 1995) is not needed (Tables 1 \& 2). This pathway has a relatively high affinity for inorganic carbon (Table 1), despite occurring mainly in organisms (Chloroflexi, some chemolithotrophs) living in environments with relatively high inorganic carbon availability (see 'Chemolithotrophs' for further details of the occurrence of the 3-hydroxypropionate pathway).

Photosynthetic growth of these organisms occurs just below the oxycline in illuminated environments. The anoxic zone is generated by a gravitational influx of particulate organic matter from (usually) oxygenic primary productivity that stoichiometrically exceeds the advective and diffusive influxes of oxygen for oxidative conversion to $\mathrm{CO}_{2}$. The depth of the oxycline varies, so there can be large variations in irradiance and its spectral distribution, since there is very significant absorption by water, especially in the infrared, as well as absorption by pigments of oxygenic photolithotrophs (Stomp et al. 2007a). This helps to rationalise the absorption properties of photosynthetic pigments in anoxygenic photosynthetic bacteria, regardless of whether they are predominantly or entirely autotrophic or are at least facultatively photoorganotrophic (Stomp et al. 2007a).

There are limits on the wavelength in the infra-red at which absorption of radiation can be used in photosynthesis, resulting from the lower energy per photon at longer wavelengths. These constrain the redox span of the photochemistry that can be performed at longer wavelengths, so that it might require the use of 2 photons to carry out the same overall metabolism as is achieved by 1 photon at shorter wavelengths (Wolstencroft \& Raven 2002, Raven \& Wolstencroft 2004, Kiang et al. 2007a,b, Raven 2007, Stomp et al. 2007a,b). Thus, direct use of a single photochemical system to reduce $\mathrm{NAD}^{+}$using sulfide as the electron donor only occurs in the Chlorobi, where the excited state bringing about the photochemistry corresponds to a wavelength of $840 \mathrm{~nm}$, although the long wavelength absorption maximum of the major light-harvesting bacteriochlorophyll is at $760 \mathrm{~nm}$ (see Falkowski \& Raven 2007). 
Indirect means of reducing $\mathrm{NAD}^{+}$using sulfide as an electron acceptor, involving proton cycling across membranes and with a photochemically generated proton-free energy difference coupled to movement of electrons from a higher to a lower redox potential, occurs in the Chromatiaceae (purple sulphur bacteria) where the effective wavelength for photochemistry is $890 \mathrm{~nm}$. However, the direct versus indirect use of photochemistry to reduce $\mathrm{NAD}^{+}$is probably a result of the less negative redox potential of the first stable reduced product of photochemistry in the purple as compared with the green sulfur bacteria, rather than the smaller redox span covered by the excitation energy in the reaction centre of the purple sulfur bacteria (Falkowski \& Raven 2007). It is not clear whether the indirect pathway of energizing $\mathrm{NAD}^{+}$reduction and sulfide oxidation in purple sulfur bacteria requires more photons absorbed per electron transferred than the direct pathway of Chlorobi, although it is known that Chlorobi typically grow deeper in the water column than purple sulfur bacteria and generally have lower maintenance costs (van Germerden \& Mas 1995).

The habitat area available for these organisms is relatively restricted; the continental shelves are only about $7 \%$ of the ocean's surface area and have a mean depth of less than about $100 \mathrm{~m}$, although very little of this provides an appropriate habitat. The Black Sea, the largest anoxic basin in the world, provides a large area of illuminated anoxic benthic habitat in its shallower regions and an area of illuminated oxycline at 85 to $120 \mathrm{~m}$ depth where the water is deeper (Gorlenko et al. 2005, Manske et al. 2005). Chlorobi are essentially the only photosynthetic primary producers at the oxycline, but their primary productivity is low because of the very low irradiance at even the top of the green sulfur bacteria layer, i.e. a maximum of 0.75 to $2.2 \mathrm{nmol}$ photon $\mathrm{m}^{-2} \mathrm{~s}^{-1}$ (presumably 400 to $700 \mathrm{~nm}$ ). The maximum rate of inorganic $\mathrm{C}$ assimilation into organic matter under these circumstances can be evaluated by assuming that all of the photons are absorbed by photosynthetic pigments, with a requirement of $8 \mathrm{~mol}$ photons per mol inorganic $\mathrm{C}$ assimilated (i.e. the minimum observed). This gives an area-based photosynthetic rate of 0.094 to $0.28 \mathrm{nmol} \mathrm{C} \mathrm{m}^{-2} \mathrm{~s}^{-1}$ or 3 to $9 \mathrm{mmol} \mathrm{C} \mathrm{m}^{-2}$ $\mathrm{yr}^{-1}$ (36 to $108 \mathrm{~g} \mathrm{C} \mathrm{m}^{-2} \mathrm{yr}^{-1}$ ). This neglects any organic carbon use in maintenance, or the lower irradiance over part of the average $12 \mathrm{~h}$ day and over the year. Even so, the productivity of the Chlorobi in the Black Sea, which probably represents their largest single habitat, is less than 1/1000 of the area-based productivity of the ocean, which has at least $115 \mathrm{~g} \mathrm{C} \mathrm{m}^{-2} \mathrm{yr}^{-1}$ (at least $50 \times 10^{15} \mathrm{~g} \mathrm{C} \mathrm{yr}^{-1}$ net productivity in the world ocean over $361 \times 10^{12} \mathrm{~m}^{2}$ of the ocean). Some Chlorobi habitats, and especially those of purple sulphur bacteria, have significantly higher solar irradiance levels
(Van Germerden \& Mas 1995). A much smaller, but interesting, habitat for Chlorobi are deep-sea hydrothermal vents (Beatty et al. 2005), where the only electromagnetic radiation available is the infra-red radiation from the hot vents. While not contributing significantly to global primary production, the ability of these Chlorobi to grow at such low irradiances raises interesting questions in cell physiology. The recent finding of a substantially increased ${ }^{14} \mathrm{C}$-inorganic carbon assimilation after light exposure of Chlorobi (Casamayor et al. 2008) requires further investigation, both with respect to the mechanism and to the implications for measurements of in situ contributions to primary productivity.

Sulfide-oxidising photolithotrophs can be in competition for reductant with sulfide-oxidising chemolithotrophs. The photolithotrophic sulfide oxidation by anoxygenic bacteria only occurs in the absence of $\mathrm{O}_{2}$ and would be expected to occur lower in the oxycline. In contrast, the chemolithotrophs need oxidants such as $\mathrm{O}_{2}$ and $\mathrm{NO}_{3}{ }^{-}$and would be expected to occur in the upper part of the oxycline; consequently, they would not cause substantial attenuation of photosynthetic radiation.

\section{Chemolithotrophs}

Chemolithotrophs oxidise $\mathrm{NH}_{4}{ }^{+}, \mathrm{NO}_{2}{ }^{-}, \mathrm{Fe}^{2+}$ and $\mathrm{S}^{2-}$ using $\mathrm{O}_{2}$ as oxidant; $\mathrm{S}^{2-}$ can also be oxidised using $\mathrm{NO}_{3}^{-}$as oxidant, with an increasing role found for Archaea in addition to Bacteria (Bach \& Edwards 2003, Francis et al. 2007, Agogué et al. 2008) (Table 2). There are also the relatively recently discovered (as a biological reality rather than a theoretical possibility) anammox bacteria that live by the oxidation of $\mathrm{NH}_{4}{ }^{+}$by $\mathrm{NO}_{2}{ }^{-}$ in anaerobic or suboxic, but not sulfidic, habitats (Schouten et al. 2004, Strous et al. 2006, Francis et al. 2007, Jensen et al. 2008) (Table 2).

Genomic and metagenomic studies have shown that the PCRC is widespread among chemolithotrophic Bacteria, and have defined the form of Rubisco involved in specific cases (Badger \& Bek 2008) (Tables 1 \& 2). Also, metagenomic studies have increased the known occurrence of the RTCAC among chemolithotrophic Bacteria (Campbell \& Cary 2004, Hügler et al. 2005), demonstrated this pathway in chemolithotrophic Archaea, and helped in demonstrating that there are variations in the enzymes involved in the pathway. Variants of the 3-hydroxypropionate pathway also occur in chemolithotrophic Archaea (Alber et al. 2006, Hallam et al. 2006) (Tables $1 \& 2$ ) as well in as in the Chloroflexaceae. Berg et al. (2007) found a novel 3-hydroxypropionate/4-hydroxybutyrate pathway in the archaean 
chemolithotroph Metallosphaera, using mainly classical rather than genomic methodology (Tables 1 \& 2). Huber et al. (2008) discovered a dicarboxylate/4hydroxybutyrate cycle in the crenarcheote Ignicoccus hospitalis (Tables 1 \& 2), also using mainly classical methodology. These 2 recently characterised pathways (Berger et al. 2007, Huber et al. 2008) have, like the RTCAC, relatively low affinities for inorganic carbon (Table 1).

A final pathway of autotrophic inorganic carbon assimilation in chemolithotrophs is the occurrence in an anammox bacterium of all the genes necessary for the acetyl-CoA pathway for the total synthesis of acetate (Table 1) using the reductant at a very negative redox potential generated in the conversion of the intermediate hydrazine to $\mathrm{N}_{2}$ (Strous et al. 2006) (Tables 1 \& 2). The acetyl-CoA pathway had previously been suggested to occur in anammox organisms on the basis of the very low natural ${ }^{13} \mathrm{C}$ level in anammox-specific lipids relative to that of $\mathrm{CO}_{2}$ in the medium (Schouten et al. 2004). This pathway seems to have a very low affinity for inorganic carbon (Table 1).

While perhaps anaplerotic rather than strictly autotrophic, the synthesis of methane from $\mathrm{CO}_{2}$ and $\mathrm{H}_{2}$, which probably accounts for up to half of the total global methanogenesis, is certainly reductive (Liu \& Whitman 2008). Furthermore, methanogens (all of which are members of the Archaea) contribute a very simple organic compound to food webs, i.e. for methanotrophs. $\mathrm{CO}_{2}$ is the inorganic carbon substrate for methanogenesis from inorganic carbon and $\mathrm{H}_{2}$. Based on the kinetics of an exchange reaction using ${ }^{14} \mathrm{CO}_{2}$, the half-saturation concentration for $\mathrm{CO}_{2}$ is $0.7 \mathrm{~mol} \mathrm{~m}^{-3}$ (Vorholt \& Thauer 1997), which is an intermediate value compared with the range for the carboxylases involved in autotrophic inorganic carbon assimilation (Table 1).

\section{SIGNIFICANCE OF CHEMOLITHOTROPHS AND ANOXYGENIC PHOTOLITHOTROPHS IN GLOBAL PRIMARY PRODUCTIVITY}

\section{Contribution of chemolithotrophs and anoxygenic photolithotrophs today}

The global biogeochemical significance of chemolithotrophs (Tables $2 \& 3$ ) in autotrophic inorganic carbon assimilation is not well constrained, although data are available from which some estimates can be made. Raven (1996) estimated the maximum inorganic carbon assimilation that could accompany nitrification in the ocean, assuming that all nitrification was chemolithotrophic and that the inorganic carbon assimilated per inorganic nitrogen oxidised from $\mathrm{NH}_{4}{ }^{+}$

Table 3. Comparison of global rates of autotrophic inorganic carbon assimilation processes that occur in aquatic environments. For additional details of the data sources and the calculations. See 'Significance of chemolithotrophs and anoxygenic photolithotrophs in global primary productivity'

\begin{tabular}{|c|c|c|}
\hline Process & 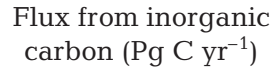 & Source \\
\hline Present nitrification & $\begin{array}{l}0.19-0.4 \\
(\text { mean } 0.3)\end{array}$ & Raven (1996), Wuchter et al. (2006) \\
\hline Present anammox & $\begin{array}{l}0.00017-0.0035 \\
(\text { mean } 0.0018)\end{array}$ & Strous et al. (1998), Francis et al. (2007) \\
\hline $\begin{array}{l}\text { Present day oxidation of biogenic sulfides by } \\
\text { chemolithotrophs and anoxygenic photolithotrophs }\end{array}$ & $\begin{array}{l}0.022-0.043 \\
(\text { mean } 0.033)\end{array}$ & $\begin{array}{l}\text { Mandernack \& Tebo (1999), } \\
\text { Turchyn \& Schrag (2004) }\end{array}$ \\
\hline Present day oxidation of hydrothermal vent sulfides & 0.002 & $\begin{array}{l}\text { Mandernack \&Tebo (1999), } \\
\text { Turchyn \& Schrag (2004) }\end{array}$ \\
\hline $\begin{array}{l}\text { Present day oxidation of sulfide from } \\
\text { basalt-hosted ocean aquifers }\end{array}$ & 0.001 & Bach \& Edwards (2003) \\
\hline $\begin{array}{l}\text { Present day methanogenesis from } \mathrm{CO}_{2} \\
\text { in wetlands and the ocean }\end{array}$ & $\begin{array}{l}0.039-0.095 \\
(\text { mean } 0.067)\end{array}$ & Liu \& Whitman (2008) \\
\hline $\begin{array}{l}\text { Present day total from chemolithotrophy } \\
\text { and anoxygenic photolithotrophy }\end{array}$ & $\begin{array}{c}0.26-0.54 \\
(\text { mean } 0.40)\end{array}$ & \\
\hline $\begin{array}{l}\text { Present day net primary productivity by marine } \\
\text { and inland waters oxygenic photolithotrophs } \\
\text { (99\% from phytoplankton) }\end{array}$ & 50 & $\begin{array}{l}\text { Field et al. (1998), Raven \& Maberly (2005) } \\
\text { del Giorgio \& Williams (2005) }\end{array}$ \\
\hline $\begin{array}{l}\text { Pre-photosynthetic (Hadean-Archaean, }<4 \text { giga- } \\
\text { annum [Ga] ago) chemolithotrophy }\end{array}$ & 0.00074 & Sleep \& Bird $(2007,2008)$ \\
\hline $\begin{array}{l}\text { Pre-oxygenic phototosynthesis (Archaean, } \\
\text { 3.8 Ga ago) primary production by chemolithotrophs } \\
\text { and anoxygenic photolithotrophs }\end{array}$ & $<1.2-<5$ & $\begin{array}{l}\text { Kharecha et al. (2005), } \\
\text { Canfield et al. (2006) }\end{array}$ \\
\hline
\end{tabular}


to $\mathrm{NO}_{3}{ }^{-}$was the highest found in laboratory cultures of nitrifying bacteria, and suggested a value of $0.19 \mathrm{Pg} \mathrm{C} \mathrm{yr}^{-1}$. It is now believed that the Crenarcheota are probably the dominant marine nitrifiers, and Wuchter et al. (2006) have estimated that inorganic carbon assimilation in the ocean associated with nitrification by these organisms as $0.4 \mathrm{Pg} \mathrm{C} \mathrm{yr}^{-1}$ (see also Agogué et al. 2008).

The other aspect of the nitrogen cycle that involves chemolithotrophy is in the anammox contribution to denitrification (Tables $2 \& 3$ ). Unlike the previously recognised chemo-organotrophic denitrification, which involved organic carbon oxidation with nitrate or nitrite as electron acceptors and the production of $\mathrm{CO}_{2}$, the anammox reaction involves autotrophic inorganic carbon assimilation with $0.065 \mathrm{~mol} \mathrm{CO}_{2}$ fixed per mol $\mathrm{N}_{2}$ released (Strous et al. 1998), i.e. $0.028 \mathrm{~g} \mathrm{C}$ assimilated from $\mathrm{CO}_{2}$ for each gram of $\mathrm{N}$ released as $\mathrm{N}_{2}$. The total $\mathrm{N}_{2}$ released in marine denitrification is poorly constrained, with values ranging from 20 to $250 \mathrm{Tg} \mathrm{N}$ $\mathrm{yr}^{-1}$ (see Tyrrell 1999, Box 1 on p. 527); the fraction of this total $\mathrm{N}_{2}$ release that involves the anammox bacteria is probably in the range 30 to $50 \%$ (Francis et al. 2007), i.e. 6 to $125 \mathrm{Tg} \mathrm{N}$ corresponding to 0.00017 to $0.0035 \mathrm{Tg} \mathrm{C}$ or 0.00000017 to $0.0000035 \mathrm{Pg} \mathrm{C}$ assimilated from $\mathrm{CO}_{2}$ each year.

Smaller values for autotrophic inorganic carbon assimilation have been suggested for organisms bringing about chemolithotrophic oxidation of sulfide to sulfate (Tables 2 \& 3). Turchyn \& Schrag (2004) cite values for sulfide oxidation in ocean sediments of 6 to 12 Tmol S $\mathrm{yr}^{-1}$. Assuming that all oxidation is biologically mediated, with the highest reported laboratory ratios of chemolithotrophic inorganic carbon assimilation to sulfide oxidation to sulfate cited by Mandernack \& Tebo (1999), the rates of global sulfide oxidation correspond to inorganic carbon assimilation rates of 0.022 to $0.043 \mathrm{Pg} \mathrm{C} \mathrm{yr}^{-1}$. These values include any contribution from photolithotrophic sulfide-oxidisers (Tables 2 \& 3), which on grounds of available habitat could only make a small contribution even though their inorganic carbon assimilation per sulfide oxidised could be higher than that for chemolithotrophs if oxidation went all the way to sulfate. Turchyn \& Schrag (2004) cite values of sulfide oxidation from

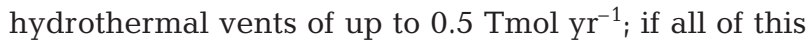
is oxidised by chemolithotrophs there could be 0.002 $\mathrm{Pg}$ inorganic carbon assimilated per year at the vents. Bach \& Edwards (2003, see also Santelli et al. 2008) considered that basalt hosted ocean aquifers, and suggested that chemolithotrophic oxidation of sulfide and ferrous iron from this source could account for $0.001 \mathrm{Pg} \mathrm{C}_{\mathrm{Cr}}^{-1}$.

The methanogens were considered above as 'honorary autotrophs,' at least in the case of those in which the carbon source is $\mathrm{CO}_{2}$ and the reductant is $\mathrm{H}_{2}$. Liu \& Whitman (2008) give marine methane production as 5 to $10 \mathrm{Tg} \mathrm{yr}^{-1}$ as $\mathrm{CH}_{4}$. Making the poorly substantiated assumption that half of this methane comes from $\mathrm{CO}_{2}$ rather than compounds containing methyl groups such as methanol or acetate, 0.004 to $0.006 \mathrm{Pg} \mathrm{C} \mathrm{yr}^{-1}$ is consumed as $\mathrm{CO}_{2}$. If wetlands are considered as an aquatic habitat, then the 92 to $237 \mathrm{Tg} \mathrm{CH}_{4} \mathrm{yr}^{-1}$ corresponds to 0.035 to $0.089 \mathrm{Pg} \mathrm{C} \mathrm{yr}^{-1}$ consumed as $\mathrm{CO}_{2}$. This gives a total for methanogenesis of 0.039 to 0.095 Pg C yr ${ }^{-1}$ consumed as $\mathrm{CO}_{2}$ (Table 3).

Summing these estimates yields global net chemolithotrophic and sulfide-oxidising anoxygenic photolithotrophic inorganic carbon assimilation rates of 0.26 to $0.54 \mathrm{Pg} \mathrm{C} \mathrm{yr}^{-1}$, with a mean of $0.40 \mathrm{Pg} \mathrm{C} \mathrm{yr}^{-1}$ (Table 3). This is $0.8 \%$ of the $50 \mathrm{Pg} \mathrm{C} \mathrm{yr}^{-1}$ of global aquatic photolithotrophic oxygenic net primary productivity (Field et al. 1998) (Table 3), but is only about $0.5 \%$ of the value suggested from measurements of respiration (del Giorgio \& Williams 2005).

Two points must be emphasised. One is that even the mean of these estimates of the contribution of chemolithotrophs and anoxygenic autotrophs is an upper limit. These estimates neglect abiological oxidations of sulfide and ferrous iron, and use the highest known stoichometries of inorganic carbon assimilation to inorganic material oxidised.

The other point is that, if these autotrophic carbon assimilation mechanisms are considered to be additional to primary production by oxygenic photolithotrophs, the source of the reduced inorganic material and oxidant must be carefully considered. The production of the former may involve oxidation of organic matter produced by previous oxygenic photolithotrophy, and the oxidant is almost invariably oxygen from oxygenic photolithotrophy, or an oxidant such as nitrate whose presence is contingent on oxygenic photosynthesis. Even the sulfide and ferrous iron from hydrothermal vents and basalt-hosted ocean aquifers are oxidised by oxygen, and these reduced species may have originated in part from subducted sediments containing biogenic sulfide and ferrous iron. For the sedimentary sulfide and the meso- and bathypelagic ammonium, there is a clear biological origin that can ultimately be traced back to oxygenic primary producers. The sulfide comes from the oxidation by sulfate of sedimented organic material, ultimately from oxygenic photolithotrophy, after the local supply of oxygen, and then nitrate, is exhausted; even the presence of sulfate in the biosphere is ultimately a result of oxidation of sulfide following the advent of oxygenic photosynthesis. The ammonium, other than that derived from combined nitrogen from fertilizers, is ultimately a result of diazotrophy, which relies directly or indirectly on oxygenic photosynthesis, as is the oxidant 
used in ammonium and nitrite nitrification. Nitrogenous fertilizers themselves depend on previous oxygenic photolithotrophy, either to generate the hydrogen used in the Haber-Bosch process from biogenic methane in making ammonia, or to supply the oxygen consumed in the Birkeland-Eyde process in making nitric acid. Of course, there are limits on how far back in palaeobiogeochemistry it is useful to go, and this will determine the extent to which different kinds of chemolithotrophy today can be said to depend on oxygenic photolithotrophy.

To put some of these arguments in quantitative terms, the first case considered is the photolithotrophic and chemolithotrophic oxidation of sulfide to sulfate. This uses sulphide generated by dissimilatory sulfate reduction. There is a net long-term burial of sulfide as pyrites of some $0.039 \mathrm{Pg} \mathrm{S} \mathrm{yr}^{-1}$ (Berner 1982), corresponding to the production of $0.014 \mathrm{Pg} \mathrm{C}$ as carbon dioxide $\left(2 \mathrm{~mol}\right.$ carbon as $\mathrm{CO}_{2}$ per $1 \mathrm{~mol}$ sulfate reduced to sulfide). To this production of $\mathrm{CO}_{2}$ must be added the $\mathrm{CO}_{2}$ released in the production of the sulfide, which is subsequently re-oxidised. With the light energy input to photolithotrophic oxidation of sulfide, the $\mathrm{CO}_{2}$ taken up in photosynthesis is equal to that released in dissimilatory sulfate reduction in producing the sulphide. For chemolithotrophic sulfide oxidation, the $\mathrm{CO}_{2}$ assimilated is less than the $\mathrm{CO}_{2}$ produced in dissimilatory production of the sulfide, so there must be more that the global net $0.014 \mathrm{Pg} \mathrm{CO}_{2}$ production per year associated with pyrites burial that is associated with the overall process of sulfate reduction to sulfide and reoxidation of some of it back to sulfate.

For the case of chemolithotrophic nitrification, oxygenic photolithotrophs growing with a given quantity of nitrogen use more energy when nitrate is the nitrogen source than when ammonium is the nitrogen source. Equating this extra energy to $\mathrm{CO}_{2}$ assimilation, the inorganic carbon assimilation that is forgone by energy-limited photolithotrophic organisms using nitrate rather than ammonium as the nitrogen source exceeds the inorganic carbon assimilated in chemolithotrophy in recycling the nitrogen excreted as ammonium to nitrate (Raven 1996). In other words, the predicted primary productivity (photolithotrophy plus chemolithotrophy) with nitrogen cycling entirely at the ammonium level is predicted to exceed that with nitrogen cycling that also involves nitrate.

These arguments show that the chemolithotrophy and non-oxygenic photolithotrophy in extant aquatic habitats are all ultimately dependent on antecedent oxygenic photolithotrophy, and that chemolitrotrophy and sulfide-based photolithotrophy only serve to partially decrease the carbon loss from the processes producing the inorganic reductant.

\section{Contributions of chemolithotrophs and anoxygenic photolithotrophs in the past}

It is widely believed that chemolithotrophy preceded phototrophy in the evolution of life on Earth. Estimates of the global primary productivity as long ago as 4.0 billion yr, which at that time was all aquatic, suggest that only $0.72 \mathrm{Tg}$ of inorganic carbon was converted to organic carbon each year (Sleep \& Bird 2007, 2008; Table 3). This annual production is only about $1 / 70000$ of annual aquatic production today, or about 1/555 of annual aquatic chemolithotrophic and anoxygenic photolithotrophic production today (Table 3). The comparison between pre-photosynthetic and extant chemolithotrophic annual production shows, among other things, the role of recycling of photosynthesis and anaerobic respiration in recycling oxidants and reductants, which facilitate chemolithotrophy.

After the evolution of anoxygenic photosynthesis not earlier than 4 billion yr ago (Sleep \& Bird 2007, 2008), there was significantly greater autotrophic inorganic carbon assimilation than before. Kharecha et al. (2005) suggest that global primary production by chemolithotrophs and anoxygenic photolithotrophs in the Archaean (3.8 billion yr ago) was not more that 1.2 Pg C yr ${ }^{-1}$, while Canfield et al. (2006) suggest up

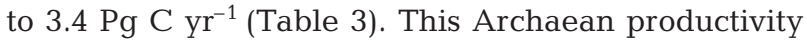
is not more than $1 / 15$ of the extant productivity based on oxygenic primary producers in the ocean and inland waters (Table 3), and about 6 times the extant productivity from chemolithotrophy and anoxygenic photolithotrophy, processes that today are largely coupled to oxygenic photolithotrophy-based food webs. However, the modelled aquatic productivity 3.8 billion yr ago was up to 5000 times the suggested chemolithotrophic productivity 4 billion yr ago (Table 3).

Since the onset of global oxygenation of the shallow ocean and the atmosphere about 2.4 billion yr ago (Sleep \& Bird 2008), there have been times when the euxinic and sulfidic conditions in the ocean have included parts of the euphotic zone, much as in the present-day Black Sea and some Antarctic fjords. There is biomarker evidence for the occurrence of sulfide-oxidising anoxygenic Bacteria of the Chlorobi and the Chromatiaceae in the marine photic zone in the mid-Proterozoic oceanic some 1.64 billion yr ago (Brocks et al. 2005). In the Neoproterozoic low-latitude glaciation 740 to 700 million yr ago, there was significant marine primary productivity as recorded in the organic carbon content of sediments. Biomarkers show that cyanobacteria and green sulphur bacteria contributed to photolithotrophy at this time, so sea ice must have been absent or at least able to permit penetration of photosynthetically active radiation during 
this 'Snowball Earth' episode (Olcott et al. 2005). There was a third time at which biomarker evidence suggests that green sulfur bacteria were important photolithotrophs in a euxinic marine photic zone, i.e. during the Permian-Triassic boundary mass extinction event some 250 million yr ago, and the 1 million yr or more thereafter (Grice et al. 2005).

\section{IMPLICATIONS FOR MEASUREMENTS IN SITU OF PRIMARY PRODUCTIVITY BY OXYGENIC PHOTOLITHOTROPHS}

For phototrophs lacking autotrophic inorganic carbon assimilation, there are 2 sources of possible interference in the ${ }^{14} \mathrm{C}$-based estimates of productivity that involve filtration and which include in the assayed particulate organic carbon organisms of the size of free-living Archaea and Bacteria and in which readings from dark are substracted from light incubations. One is the occurrence of light stimulation of anaplerotic inorganic ${ }^{14} \mathrm{C}$ assimilation in photo-organotrophs with rhodopsin- or bacteriochlorophyll-based stimulation of growth. This is unlikely to be significant, since anaplerotic inorganic carbon assimilation contributes not more than $5 \%$ of the total net carbon use in growth, so that the light-stimulated component of anaplerotic inorganic carbon assimilation would only be $5 \%$ of $1 \%$ (see 'Organisms with energy-transforming photochmistry but not capable of autotrophic $\mathrm{CO}_{2}$ assimilation) or $0.05 \%$ of photolithotrophic primary production. This would not be detected in ${ }^{14} \mathrm{C}$ estimates of primary production. The other is the occurrence of efflux of ${ }^{14} \mathrm{C}$-labelled dissolved organic carbon from oxygenic photolithotrophs, followed by assimilation by the photo-organotrophs. This second possibility seems unlikely to be significant, because dilution with unlabelled dissolved organic carbon in seawater makes it unlikely that recently produced dissolved organic matter is more accessible to the photo-organotrophs than is the average of the predominantly refractory dissolved organic matter in natural waters.

A related question is the extent to which chemolithotrophy and anoxygenic photolithotrophy are experimentally separable from oxygenic photolithotrophy in field measurements of primary productivity that are attributed to oxygenic organisms. The answer is that, with the probable exception of nitrifiers, they are generally spatially separate from the oxygenic phytoplankton. This is clearly the case for autotrophs at hydrothermal vents and in basalt-hosted marine aquifers, as well as for sulfide oxidisers at the oxycline of sulfidic sediments and bulk water below the upper mixed layer or epilimnion. Similarly for the anammox bacteria, their restriction to anoxic or suboxic habitats means ready separation from measurements on oxygenic photolithotrophs.

The situation for nitrifiers is less clear; it used to be thought that these organisms are subject to photoinhibitition and so would not significantly affect measurements in the upper mixed layer or epilimnion. However, the analysis by Yool et al. (2007) on the specific rate of nitrification (i.e. normalised to ammonium concentration) shows no significant decrease with depth and suggests that half of ocean nitrification occurs above the permanent thermocline, i.e. with a significant amount going on in the euphotic zone. Since nitrification consumes ammonium, carbon dioxide and oxygen, its occurrence in the euphotic zone would (1) add a nitrification step between some of the disappearance of ammonium from solution and the appearance of organic particulate nitrogen, (2) contribute to ${ }^{14} \mathrm{C}$ inorganic carbon assimilation in 'dark' bottles and 'light' bottles, and (3) be a positive component of oxygen uptake under dark conditions and a negative component of net oxygen production in the light. The studies indicating photoinhibition of nitrification in the surface ocean were based on studies with nitrifying bacteria, rather than with the predominant Crenarcheota (Yool et al. 2007).

\section{DISCUSSION AND CONCLUSIONS}

There is a great diversity of autotrophs sensu lato, other than oxygenic phototolithotrophs, in aquatic habitats today. The chemolithotrophs use a wide range of reductants and a number of oxidants other than oxygen. Many of the anoxygenic phototrophs have bacteriochlorophyll-based photochemistry and use photosystems resembling the PSI or PSII of oxygenic phototolithotrophs. All of these photosystems have a common evolutionary origin (Raymond et al. 2003, Sadekar et al. 2006). The remaining phototrophs, none of which can carry out autotrophic inorganic carbon assimiliation, have rhodopsin-like energy-conserving photochemistry.

The non-oxygenic organisms that carry out autotrophic inorganic carbon assimilation either have the PCRC (as do all oxygenic photolithotrophs) or 1 of 4 (5 if methanogens are included) other pathways of inorganic carbon assimilation (Table 1). The phylogenetic distribution of these pathways probably involves horizontal gene transfer. The properties of some of these pathways in terms of inorganic carbon affinity, absence of competition between oxygen and $\mathrm{CO}_{2}$, and lower ATP consumption per inorganic carbon assimilated, are apparently more appropriate for 
photosynthesis in water in equilibrium with today's atmosphere than the PCRC using Rubisco (Table 1). The absence of any of the alternative pathways of autotrophic inorganic carbon assimilation from oxygenic photolithotrophs is presumably a result of noncompetitive inhibition, or inactivation, of the other pathway by oxygen, and/or mechanistic problems with horizontal gene transfer and the replacement of the incumbent PCRC by an alternative pathway of autotrophic inorganic carbon assimilation (Raven et al. 2008a,b).

In today's aquatic habitats, the combined contribution of anoxygenic photolithotrophs and chemolithotrophs to autotrophic inorganic carbon assimilation is 0.5 to $1.0 \%$ of the net primary productivity attributable to oxygenic photolithotrophs (Table 2). The activities of anoxygenic phototrophs lacking autotrophic inorganic carbon assimilation using bacteriochlorophyll- or rhodopsin-like pigments probably increase, by $1 \%$ or less, the conversion of dissolved organic carbon into particulate organic carbon by euphotic zone chemoorganotrophic Archaea and Bacteria. These contributions to aquatic productivity today by non-oxygenic autotrophs and non-autotrophic phototrophs are all dependent indirectly on the activities of oxygenic photolithotrophs. Overall, the activities of non-oxygenic autotrophs do not balance the $\mathrm{CO}_{2}$ production involved in generating the anoxic environment and biogenic sulfide used by anoxygenic photolithotrophs and the biogenic sulfide, ammonium, nitrite and oxygen (or other oxidants) used by chemolithotrophs. There is minimal interference of the activities of phototrophs lacking autotrophic inorganic carbon assimilation, non-oxygenic photolithotrophs or chemolithotrophs with measurement of in situ inorganic carbon assimilation by oxygenic photolithotrophs.

Before the advent of oxygenic photolithotrophy at least 2.32 to 2.45 billion yr ago (Rasmussen et al. 2008), the activity of anoxygenic photolithotrophs and of chemolithotrophs was greater than the present-day values, largely as a result of the availability of the entire aquatic euphotic zone to anoxygenic photolithotrophs. Before anoxygenic photolithotrophs evolved 4 billion yr ago, there was only limited productivity by chemolithotrophs. Even after oxygenic photolithophs evolved and the atmosphere became oxygenated, there was a long period in which the ocean was euxinic and sulfidic, giving some productivity by anoxygenic photolithotrophs at the base of the euphotic zone, as in the Black Sea and some Antarctic fjords today. Since oxygenation of essentially the whole ocean became the norm in the late Proterozoic, there have been periods in which the ocean was euxinic and sulfidic, e.g. at the Permian-Triassic boundary.
Acknowledgements. I acknowledge the kind invitation by the Group on Aquatic Productivity to lecture at their meeting in Eilat in 2008; this manuscript is an outcome of preparing the lecture and was also in part inspired by an invitation by Ian Joint to lecture at a 'Sequencing the Seas' workshop in London in 2007. Work on inorganic carbon assimilation in aquatic micro-organisms in J.A.R.'s laboratory is supported by the Natural Environment Research Council, UK. I also thank the handling editor, Hugh McIntyre, Peter J. LeB. Williams and 2 other anonymous referees; their input greatly improved the manuscript. The University of Dundee is a registered Scottish charity, No: SC015096.

\section{LITERATURE CITED}

Agogué H, Brink M, Dinasquet J, Herndl GJ (2008) Major gradients in putatively nitrifying and non-nitrifying Archaea in the deep North Atlantic. Nature 456:788-791

Alber B, Olinger M, Rieder A, Kockelkorn D, Jobst B, Hügler M, Fuchs G (2006) Malonyl-coenzyme A reductase in the modified 3-hydroxypropionate cycle for autotrophic carbon fixation in archaeal Metallosphaera and Sulfolobus spp. J Bacteriol 188:8551-8559

- Armbrust EV, Berges JA, Bowler C, Green BR, and others (2004) The genome of the diatom Thalassiosira pseudonana. Ecology, evolution and metabolism. Science 306:79-86

Atamna-Ismaeel N, Sabehi G, Sharon I, Witzel KP and others (2008) Widespread distribution of proteorhodopsins in freshwater and brackish ecosystems. ISME J 2:656-662

Bach W, Edwards KJ (2003) Iron and sulphide oxidation within the basaltic oceanic crust: implications for chemoautotrophic biomass production. Geochim Cosmochim Acta 67:3871-3887

Badger MR, Bek EJ (2008) Multiple Rubisco forms in proteobacteria: their functional significance in relation to $\mathrm{CO}_{2}$ acquisition by the CBB cycle. J Exp Bot 59:1525-1541

Baliga NS, Bonneau R, Facciotti MT, Pan M and others (2004) Genome sequence of Haloarcula marismortui: a halophilic archaeon from the Dead Sea. Genome Res 14:2221-2234

Beatty JT, Overmann J, Lince MT, Manske AK and others (2005) An obligately photosynthetic bacterial anaerobe from a deep-sea hydrothermal vent. Proc Natl Acad Sci USA 102:9306-9310

Béjà O, Spudlich EN, Spudlich JL, Leclerc M, DeLong EF (2001) Proteorhodopsin phototrophy in the ocean. Nature 411:786-789

Berg IA, Kockelkorn D, Buckel W, Fuchs G (2007) A 3hydroxypropionate/4-hydroxybutyrate carbon dioxide assimilation pathway in Archaea. Science 318:1782-1786

Berner RA (1982) Burial of organic-carbon and pyrite sulphur in the modern ocean - its geochemical and environmental significance. Am J Sci 282:451-473

Biebl H, Wagner-Döbler I (2006) Growth and bacterochlorophyll formation in taxonomically diverse aerobic anoxygenic phototrophic bacteria in chemostat culture: influence of light regimen and starvation. Process Biochem 41:2153-2159

Bowler C, Allen AE, Badger JH, Grimwood J and others (2008) The Phaeodactylum genome reveals the evolutionary history of diatom genomes. Nature 456:239-244

Brocks JJ, Love GD, Summons RE, Knoll AH, Logan GA, Bowden SA (2005) Biomarker evidence for green and purple sulphur bacteria in a stratified Palaeoproterozoic sea. 
Nature 437:866-870

Bryant DA, Frigaard NU (2006) Prokaryote photosynthesis and phototrophy illuminated. Trends Microbiol 14: 488-495

Bryant DA, Costas AMG, Maresca JA, Chew AGM and others (2007) Candidatus Chloracidobacterium thermophilum: an aerobic phototrophic acidobacterium. Science 317: $523-526$

Campbell BJ, Cary SC (2004) Abundance of reverse tricarboxylic acid cycle genes in free-living microorganisms at deep-sea hydrothermal vents. Appl Environ Microbiol 70: 6282-6289

Canfield DE, Rosing MT, Bjerrum C (2006) Early anaerobic metabolisms. Philos Trans R Soc Lond B Biol Sci 361: 1819-1836

> Cannon GC, Bradbourne CE, Aldrich HC, Barker SH, Heinhorst S, Shively JM (2001) Microcompartments in prokaryotes: carboxysomes and related bodies. Appl Environ Microbiol 67:5351-5361

Casamayor EO, García-Cantizano J, Pedrós-Alió C (2008) Carbon dioxide fixation in the dark by photosynthetic bacteria in sulphide-rich stratified lakes with oxic-anoxic interfaces. Limnol Oceanogr 53:1193-1203

Cassar N, Laws EA (2007) Potential contribution of $\beta$-carboxylases to photosynthetic carbon isotope fractionation in a marine diatom. Phycologia 46:307-314

Codd GA, Marsden WJN (1984) The carboxysomes (polyhedral bodies) of autotrophic prokaryotes. Biol Rev 59: $389-422$

- Crowe SA, Jones CA, Katsev S, Magen C and others (2008) Phytoferrotrophs thrive in an Archean Ocean analogue. Proc Natl Acad Sci USA 105:15938-15943

Danon A (1983) Bacteriorhodopsin-mediated $\mathrm{CO}_{2}$ photoassimilation in the Dead Sea. Limnol Oceanogr 28:33-41

- Danon A, Caplan SR (1977) $\mathrm{CO}_{2}$ fixation by Halobacterium halobium. FEBS Lett 74:255-258

del Giorgio PA, Williams PJleB (2005) The global significance of respiration in aquatic ecosystems: from single cells to the biosphere. In: del Giorgio PA, Williams PJleB (eds) Respiration in aquatic systems. Oxford University Press, Oxford, p 267-303

Eisen JA, Nelson KE, Paulsen IT, Heidelberg JF and others (2002) The complete genome sequence of Chlorobium tepidum TLS, a photosynthetic, anaerobic, green-sulfur bacterium. Proc Natl Acad Sci USA 99:9509-9514

Falkowski PG, Raven JA (2007) Aquatic photosynthesis, 2nd edn. Princeton University Press, Princeton, NJ

- Field CB, Behrenfeld MJ, Randerson JT, Falkowski P (1998) Primary production in the biosphere: integrating terrestrial and oceanic components. Science 281:237-240

Francis CA, Beman JM, Kuypens MMM (2007) New processes and players in the nitrogen cycle: the microbial ecology of anaerobic and archaeal ammonia oxidation. ISME J 1:19-27

Friedmann S, Alber BE, Fuchs G (2006) Properties of succinylCoenzyme A:D-citramalyl coenzyme A transferase and its role in the autotrophic 3-hydroxypropionate cycle of Chloroflexus auriantacus. J Bacteriol 188:6460-6468

Frigaard NU, Chew AGM, Li H, Maresca JA, Bryant DA (2003) Chlorobium tepidum: insights into the structure, physiology and metabolism from the complete genome sequence. Photosynth Res 78:93-117

Fuchs BM, Spring S, Teeling H, Quast C and others (2007) Characterization of a marine gammaproteobacterium capable of aerobic anoxygenic photosynthesis. Proc Natl Acad Sci USA 104:2891-2896

Furdui C, Ragsdale SW (2000) The role of pyruvate:ferredoxin oxidoreductase in pyruvate synthesis during autotrophic growth by the Wood-Ljungdahl pathway. J Biol Chem 275:28494-28499

> Gasol JM, Pinhassi J, Alonso-Sáez L, Ducklow H and others (2008) Towards a better understading of microbial carbon flux in the sea. Aquat Microb Ecol 53:21-38

> Gest H, Blankenship RE (2004) Time line of discoveries: anoxygenic bacterial photosynthesis. Photosynth Res 80: $59-70$

Giordano M, Beardall J, Raven JA (2005) $\mathrm{CO}_{2}$ concentrating mechanisms in algae: mechanisms, environmental modulation, and evolution. Annu Rev Plant Biol 56:99-131

Giovannoni SJ, Bibbs L, Cho JC, Stapels MD and others (2005) Proteorhodopsin in the ubiquitous marine bacterium SAR11. Nature 438:82-85

Giraud E, Fleischman D (2004) Nitrogen-fixing symbiosis between photosynthetic bacteria and legumes. Photosynth Res 82:115-130

Goericke R (2002) Bacteriochlorophyll a in the ocean: Is anoxygenic bacterial photosynthesis important? Limnol Oceanogr 47:290-295

Gorlenko VM, Mikheev PV, Rusanov II, Pimenov NV, Ivanov MV (2005) Ecophysiological properties of photosynthetic bacteria from the Black Sea chemocline zone. Microbiology 74:201-209

Grice K, Cao C, Love GD, Böttcher ME and others (2005) Photic zone euxinia during the Permian-Triassic superanoxic event. Science 307:706-709

Hallam SJ, Mincer TJ, Schleper C, Preston CM, Roberts K, Richardson PM, DeLong EF (2006) Pathways of carbon assimilation and ammonia oxidation suggested by environmental genomic analysis of marine Crenarcheota. PLoS Biol 4(4):e95

> Heinnickel M, Golbeck JH (2007) Heliobacterial photosynthesis. Photosynth Res 92:35-53

> Herter S, Fuchs G, Bacher A, Eisenreich W (2002) A bicyclic autotrophic $\mathrm{CO}_{2}$ fixation pathway in Chloroflexus aurianticus. J Biol Chem 277:20277-20283

> Höfle MG, Kirchman DL, Christen R, Brettar I (2008) Molecular diversity of bacterioplankton: link to a predictive biogeochemistry of pelagic ecosystems. Aquat Microb Ecol 53:39-58

> Hoppe HG, Gocke K, Koppe R, Begler C (2002) Bacterial growth and primary production along a north-south transect of the Atlantic Ocean. Nature 416:168-171

Huber H, Gallenberger M, Jahn E, Berg IA, Kockelkorn D, Eisenreich W, Fuchs G (2008) A dicarboxylate/4-hydroxybutyrate autotrophic carbon assimilation in the hyperthermophilic Archaeum Ignicoccus hospitalis. Proc Natl Acad Sci USA 105:7851-7856

Hügler M, Krieger RS, Jahn M, Fuchs G (2003) Characterization of acetyl-CoA/propionyl-CoA carboxylase in Metallosphaera sedula. Carboxylating enzyme in the 3-hydroxypropionate cycle for autotrophic carbon fixation. Eur J Biochem 270:736-744

Hügler M, Wirsen CO, Fuchs G, Taylor CD, Sievert SF (2005) Evidence for autotrophic $\mathrm{CO}_{2}$ fixation via the reductive tricarboxylic acid cycle by members of the $\varepsilon$ subdivision of proteobacteria. J Bacteriol 187:3020-3027

Jensen MM, Kuypers MMM, Lavik G, Thamdrup B (2008) Rates and regulation of the anaerobic ammonium oxidation and denitrification in the Black Sea. Limnol Oceanogr 53:23-36

Kanao T, Kawamura H, Fukui T, Atomi H, Iwanaka T (2002) Characterization of isocitrate dehydrogenase from the green sulphur bacterium Chlorobium limicola-carbon dioxide-fixing enzyme in the reductive tricarboxylic acid 
cycle. Eur J Biochem 269:1926-1931

Kharecha P, Kasting J, Siefert J (2005) A coupled atmosphere-ecosystem model of the early Archean Earth. Geobiology 3:53-76

Kiang NY, Siefert J, Govindjee, Blankenship RE (2007a) Spectral signatures of photosynthesis. I. Review of Earth organisms. Astrobiology 7:222-251

Kiang NY, Segura A, Tinetti G, Govindjee, Blankenship RE, Siefert J, Crisp D, Meadows VS (2007b) Spectral signatures of photosynthesis. II. Coevolution with other stars and the atmosphere on extrasolar worlds. Astrobiology $7: 252-274$

Klatt CG, Bryant DA, Ward DM (2007) Comparative genomics provides evidence for the 3-hydoxypropionate autotrophic pathway in filamentous anoxygenic phototrophic bacteria and in hot spring microbial mats. Environ Microbiol 9:2067-2078

Kolber ZS, Plumley FG, Lang AS, Beatty JT and others (2001) Contribution of aerobic photoheterotrophic bacteria to the carbon cycle of the ocean. Science 292:2492-2495

- Kroth PG, Chiovitti A, Gruber A, Martin-Jezequel V and others (2008) A model for carbohydrate metabolism in the diatom Phaeodactylum tricornutum deduced from whole genome analysis. PLoS One 3(1):e1426

Larimer FW, Chain P, Hauser L, Lamerdin J and others (2004) Complete genome sequence of the metabolically versatile photosynthetic bacterium Rhodopseudomonas palustris. Nat Biotechnol 22:55-61

Lebedeva NV, Malinina NV, Ivanovsky RN (2002) A comparative study of the isocitrate dehydrogenases of Chlorobium limicola and Rhodopseudomonas palustris. Microbiology 71:657-661

Liu Y, Whitman WB (2008) Metabolic, phylogenetic, and ecological diversity of the methanogenic Archaea. Ann NY Acad Sci 1125:171-189

Man D, Wang W, Sabehi G, Aravind L and others (2003) Diversification and spectral tuning in marine proteorhodopsins. EMBO J 22:1725-1731

> Mandernack KW, Tebo BM (1999) In situ sulphide removal and $\mathrm{CO}_{2}$ fixation rates at deep-sea hydrothermal vents and the oxic/anoxic interface in Framvaren Fjord, Norway. Mar Chem 66:201-213

Manske AK, Glaeser J, Kuypers MMM, Overmann J (2005) Physiology and phylogeny of green sulphur forming a monospecific phototrophic assemblage at a depth of 100 meters in the Black Sea. Appl Environ Microbiol 71: 8049-8060

> McGinn PJ, Morel FMM (2008) Expression and inhibition of the carboxylating and decarboxylating enzymes in the photosynthetic $\mathrm{C}_{4}$ pathway of marine diatoms. Plant Physiol 146:300-309

Merchant SS, Prochnik SE, Vallon O, Harris HM and others (2007) The Chlamydomonas genome reveals the evolution of key animal and plant functions. Science 318:245-250

Mongodin EF, Nelson KE, Daugherty S, Deboy RT and others (2005) The genome of Salinibacter ruber: convergence and gene exchange among hyperhalophilic bacteria and archaea. Proc Natl Acad Sci USA 102:18147-18152

Moran MA, Miller WL (2007) Resourceful heterotrophs make the most of light in the ocean. Nat Rev Microbiol 5:792-800

Müller V (2003) Energy conservation in acetogenic bacteria. Appl Environ Microbiol 69:6345-6353

Ng WV, Kennedy S, Mahairas B, Bergquist M and others (2000) Genome sequence of Halobacterium species NRC-1. Proc Natl Acad Sci USA 97:12176-12181

$>$ Oesterhelt D, Stoeckenius W (1973) Functions of a new photoreceptor membrane. Proc Natl Acad Sci USA 70:
$2853-2857$

> Olcott AN, Sessions AL, Corsetti FA, Kaufman AJ, Flavio de Oliviera T (2005) Biomarker evidence for photosynthesis during Neoproterozoic glaciation. Science 310:471-474

Pickett MW, Williamson MP, Kelly DJ (1994) An enzyme and C-13-NMR study of carbon metabolism in Heliobacteria. Photosynth Res 41:75-88

Price GD, Badger MR, Woodger FJ, Long BM (2008) Advances in understanding the cyanobacterial $\mathrm{CO}_{2}$-concentrating mechanism (CCM): functional components, $\mathrm{Ci}$ transporters, diversity, genetic regulation and prospects for engineering into plants. J Exp Bot 59:1441-1461

Rasmussen B, Fletcher IR, Brocks JJ, Kilburn MR (2008) Reassessing the first appearance of eukaryotes and cyanobacteria. Nature 455:1101-1104

Raven JA (1996) The role of autotrophs in global $\mathrm{CO}_{2}$ cycling. In: Lidstrom ME, Tabita FR (eds) Microbial growth on $\mathrm{C}_{1}$ compounds. Proceedings of the 8th International Symposium on Microbial Growth on $\mathrm{C}_{1}$ Compounds. Kluwer Academic Publishers, Dordrecht, p 351-358

Raven J (2007) Photosynthesis in watercolours. Nature 448:418

Raven JA, Maberly SC (2005) Plant productivity in inland waters. In: Papageorgiou GC, Govindjee (eds) Chlorophyll fluorescence: a signature of photosynthesis. Kluwer Academic Publishers, Dordrecht, p 779-793

Raven JA, Wolstencroft RD (2004) Constraints on photosynthesis on Earth and Earth-like planets. In: Norris RP, Stootman FH (eds) Bioastronomy 2002-life among the stars: Proceedings, 213th Symposium of the International Astronomical Union, Hamilton Beach, Australia. Astronomical Society of the Pacific, San Francisco, CA, p 305-308

Raven JA, Yin ZH (1998) The past, present and future of nitrogenous compounds in the atmosphere and their interactions with plants. New Phytol 139:205-219

Raven JA, Giordano M, Beardall J (2008a) Insights into the evolution of CCMs from comparisons with other resource acquisition and assimilation processes. Physiol Plant 133: $4-14$

> Raven JA, Cockell CS, De La Rocha C (2008b) The evolution of inorganic carbon concentrating mechanisms in photosynthesis. Philos Trans R Soc Lond B Biol Sci 363: 2641-2650

> Raymond J, Zhaxybayeva O, Gogarten JP, Blankenship RE (2003) Evolution of photosynthetic prokaryotes: a maximum-likelihood mapping approach. Philos Trans R Soc Lond B Biol Sci 358:223-230

Reinfelder JR, Kraepiel AML, Morel FMM (2000) Unicellular $\mathrm{C}_{4}$ photosynthesis in a marine diatom. Nature 407: 996-999

Roberts K, Granum E, Leegood RC, Raven JA (2007a) Carbon acquisition by diatoms. Photosynth Res 93:79-88

> Roberts K, Granum E, Leegood RC, Raven JA (2007b) $\mathrm{C}_{3}$ and $\mathrm{C}_{4}$ pathways of photosynthetic carbon assimilation in marine diatoms are under genetic, not environmental, control. Plant Physiol 145:230-235

Rusching G, Müller U, Willnow P, Hopfner T (1976) $\mathrm{CO}_{2}$ reduction to formate by $\mathrm{NADH}$ catalysed by formate dehydrogenase from Pseudomonas oxalaticus. Eur J Biochem 70:325-330

- Sadekar S, Raymond J, Blankenship RE (2006) Conservation of distantly related membrane proteins: Photosynthetic reaction centers share a common structural core. Mol Biol Evol 23:2001-2007

Santelli CM, Orcutt BN, Banning E, Bach W and others (2008) Abundance and diversity of microbial life in the ocean 
crust. Nature 453:653-656

Sattley WM, Madigan MT, Swingley WS, Cheung PC and others (2008) The genome of Heliobacterium modesticaldum, a phototrophic representative of the Firmicutes containing the simplest photosynthetic apparatus. J Bacteriol 190:4687-4696

Schouten S, Strous M, Kuypers MMM, Rijpstra WIC, Baas M, Schubert CJ, Jetten MSM, Sinninghe Damsté JS (2004) Stable carbon isotopic fractionations associated with inorganic carbon fixation by anaerobic ammonium-oxidising bacteria. Appl Environ Microbiol 70:3785-3788

Sharma AK, Zhaxybayeva O, Papke RT, Doolittle WF (2008) Actinorhodopsins: proteorhodopsin-like gene sequences found predominantly in non-marine environments. Environ Microbiol 10:1039-1056

Sirevåg R (1995) Carbon metabolism in green bacteria. In: Blankenship RE, Madigan MT, Bauer CE (eds) Anoxygenic photosynthetic bacteria. Kluwer Academic Publishers, Dordrecht, p 871-883

Sleep NH, Bird DK (2007) Niches of the pre-photosynthetic biosphere and geologic preservation of Earth's earliest ecology. Geobiology 5:101-117

Sleep NH, Bird DK (2008) Evolutionary ecology during the rise of dioxygen in the Earth's earliest biosphere. Philos Trans R Soc Lond B Biol Sci 363:2651-2664

Stomp M, Huisman J, Stal LJ, Matthijs HCP (2007a) Colorful niches of phototrophic microorganisms shaped by vibrations of the water molecule. ISME J 1:271-282

Stomp M, Huisman J, Vöros L, Pick FR, Laamanan M, Haverjkamp T, Stal LJ (2007b) Colourful coexistence of red and green picocyanobacteria in lakes and seas. Ecol Lett 10:290-298

- Strous M, Heiknen JJ, Kuenen JG, Jetten MSM (1998) The sequencing batch reactor as a powerful tool for the study of slowly growing anaerobic ammonium-oxidising microorganisms. Appl Microbiol Biotechnol 50:589-596

Strous M, Pelletier E, Mangenot S, Rattei T and others (2006) Deciphering the evolution of an anammox bacterium from a community genome. Nature 440:790-794

Swingley WD, Sadekar S, Mastrian SD, Matthies HJ and others (2007) The complete genome sequence of Roseobacter denitricans reveals a mixotrophic rather than photosynthetic metabolism. J Bacteriol 189:683-690

Tabita FR (1995) The biochemistry and metabolic regulation of carbon metabolism and $\mathrm{CO}_{2}$ fixation in purple bacteria.

Editorial responsibility: Hugh MacIntyre, Dauphin Island, Alabama, USA
In: Blankenship RE, Madigan MT, Bauer CE (eds) Anoxygenic photosynthetic bacteria. Kluwer Academic Publisher, Dordrecht, p 885-914

> Tabita FR, Satagopan S, Hanson TE, Kreel NE, Scott SS (2008) Distinct form I, II, III, and IV Rubisco proteins from the three kingdoms of life provide clues about Rubisco evolution and structure/function relationships. J Exp Bot 59: $1515-1524$

Tcherkez GGB, Farquhar GD, Andrews TJ (2006) Despite slow catalysis and confused substrate specificity, all ribulose bisphosphate carboxylases may be nearly perfectly optimized. Proc Natl Acad Sci USA 103:7246-7251

Turchyn AV, Schrag DP (2004) Oxygen isotope constraints on the sulphur cycle over the past 10 million years. Science 303:2004-2007

$>$ Tyrrell T (1999) The relative influences of nitrogen and phosphorus on oceanic primary productivity. Nature 400: 525-531

van Gemerden H, Mas J (1995) Ecology of phototrophic sulphur bacteria. In: Blankenship RE, Madigan MT, Bauer CE (eds) Anoxygenic photosynthetic bacteria, Kluwer Academic Publishers, Dordrecht, p 49-85

$>$ Vorholt JA, Thauer RK (1997) The active species of ' $\mathrm{CO}_{2}$ ' utilized by formylmethanofuran dehydrogenase from methanogenic Archaea. Eur J Biochem 248:919-924

Wolstencroft RD, Raven JA (2002) Photosynthesis: likelihood of occurrence and possibility of detection on Earth-like planets. Icarus 157:535-548

Wuchter C, Abbas B, Coolen MJL, Herfort L and others (2006) Archaeal nitrification in the ocean. Proc Natl Acad Sci USA 103:12317-12322

> Yool A, Martin AP, Fernández C, Clark DR (2007) The significance for nitrification for oceanic new production. Nature 447:999-1002

Yurkov VV, Beatty JT (1998) Aerobic anoxygenic phototrophic bacteria. Microbiol Mol Biol Rev 62:695-724

- Yurkov VV, van Gemerden H (1993) Impact of light-dark regimen on growth rate, biomass formation and bacteriochlorophyll synthesis in Erythromicrobium hydrolyticum. Arch Microbiol 159:84-89

> Zehr JP, Bench SR, Carter BJ, Hewson I and others (2008) Globally distributed uncultivated oceanic $\mathrm{N}_{2}$-fixing cyanobacteria lack oxygenic photosystem II. Science 322: $1110-1112$

Submitted: August 5, 2008; Accepted: April 27, 2009 Proofs received from author(s): July 3, 2009 